\title{
Offshoring, employment, and aggregate demand
}

\author{
Enno Schröder ${ }^{1}$ (D)
}

\begin{abstract}
The article uses a demand-constrained small-open-economy model in the tradition of Keynes and Kalecki to study the effects of offshoring on aggregate demand and domestic employment. Offshoring is represented as labor-saving importusing technical change. The results depend on the behavior of the markup on unit costs. If higher markups absorb the competitiveness gain, the scale effect of labor demand is negative, and offshoring unambiguously reduces domestic demand and employment. If the markup remains constant, the net effect of offshoring on domestic demand and employment is ambiguous; it depends crucially on the price elasticity of exports.
\end{abstract}

Keywords Offshoring · Global value chains · Trade flows · Labor demand . Unemployment · Aggregate demand · Germany

JEL Classification $\mathrm{F} 16 \cdot \mathrm{F} 41 \cdot \mathrm{J} 23$

\section{Introduction}

Offshoring refers to the relocation of production activity to a foreign country. The output of the offshored activity is then imported for use as an input to domestic production. The primary objective of offshoring, according to enterprise surveys in advanced economies, is to cut costs (OECD 2007). The immediate and observable

Enno Schröder

e.schroeder@tudelft.nl

1 Department Values, Technology and Innovation, Delft University of Technology, Jaffalaan 5, 2628 BX Delft, Netherlands 
effect of offshoring on the domestic economy is a job loss: the tasks that had previously been performed by workers on domestic territory are now performed by workers abroad. Within the confines of the pure theory of trade, the question to what extent offshoring influences aggregate employment cannot be asked - by virtue of the full-employment assumption, the jobs lost in one industry will be gained in another, and the ease with which this structural change will occur depends upon the extent of frictions and rigidities in factor markets.

This article is concerned with the relation between offshoring and demanddeficient unemployment. It uses a small-open-economy macro model to study the consequences of offshoring when output is demand-constrained and full employment is a special case. In an otherwise standard model in the tradition of John Maynard Keynes and Michal Kalecki, offshoring is introduced as labor-saving import-using technical change. The model economy combines two factors of production - domestic labor and imports - to produce a good that can be consumed and invested domestically or exported. Equilibrium output depends on domestic expenditure, which is a function of the wage bill and profits, and on foreign expenditure, which is a function of the real exchange rate. Labor demand follows from goods market equilibrium. It will be shown that offshoring creates unemployment in the model economy if the loss of domestic labor income reduces domestic demand to a greater extent than the improvement in international price competitiveness raises foreign demand. A given employment level can be sustained only if the price elasticity of export demand is high - otherwise offshoring creates unemployment. If firms use the cost advantages gained by offshoring to raise markups, rather than to lower prices, offshoring reduces employment and domestic demand unambiguously.

The model intends to illuminate a facet of the German economy from 1995 to 2005, Germany's “sick man period". During that time period, Germany maintained world market shares in manufacturing trade while most high-income countries lost market shares and emerging markets gained. The relatively strong export performance represents a foreign demand injection; a foreign trade multiplier process, it could be argued, should have generated robust income and expenditure growth. But the macroeconomic performance of the German economy was poor by historical standards and poor in comparison with other high-income countries, and unemployment remained high throughout the sick man period. The coexistence of export boom and near stagnation suggests that some kind of demand leakage was counteracting the foreign demand injection. Offshoring is a candidate explanation. A high share of foreign value added in the value of exports implies that a country's export growth can be decoupled to a considerable degree from its aggregate income and employment growth (Timmer et al. 2013). A rising share of foreign value added in domestic production implies that income and employment may stagnate even as gross exports and domestic demand are growing. Offshoring increases the share of foreign value added in domestic production; offshoring can potentially contribute to an explanation of the sick man of Europe.

The literature has modeled offshoring as trade in inputs (Jones 2000), trade in factor services (Bhagwati et al. 2004), or trade in tasks (Grossman and Rossi-Hansberg 2008). Most models include two factors of production - high-skilled labor and lowskilled labor - and embody the assumption that real wages adjust to clear factor 
markets. With net effects on aggregate employment ruled out by assumption, the primary object of study is the reward of high-skilled labor relative to low-skilled labor.

Full-employment trade models have been amended by the inclusion of labor market imperfections that give rise to frictional unemployment. Davidson et al. (1999) introduce Diamond-Mortensen-Pissarides search-and-matching frictions in a Heckscher-Ohlin model, and Helpman and Itskhoki (2010) introduce the same type of frictions in a heterogeneous-firm model that builds on Melitz (2003). ${ }^{1}$ A research question in this branch of literature is whether the presence of labor market imperfections alters some of the propositions that emanate from frictionless trade models. A second question concerns the impact of trade on the natural rate of unemployment. The models, it should be noted, assume that in the absence of frictions, the natural rate of unemployment would be zero, with or without international trade. Trade may influence the natural rate of unemployment because labor market frictions vary by region or sector, and trade-initiated structural change alters the "weights" of regions or sectors in the aggregate economy. This article has a different focus and studies a type of unemployment that does not originate in the labor market; it studies under what conditions offshoring leads to demand-deficient unemployment.

The article is structured as follows. Section 2 presents empirical evidence supporting the case that German firms were offshoring production to a greater extent than firms in other high-income countries. Section 3 presents a standard Keynes-Kalecki model and adds labor-saving import-using technical change to it. Section 4 explains the results, whereas the derivations are in the Appendix A. Section 5 discusses the connection between the model and the German experience in the sick man period.

\section{Empirical evidence}

National accounts and balance-of-payments statistics report gross trade flows $\left(X^{\$}\right)$. The value of a country's gross exports contains foreign value added, since, in general, domestic production makes use of imported intermediate goods and services and raw materials. Gross exports can be contrasted with value added exports $\left(V A X^{\$}\right)$, a concept introduced by Johnson and Noguera (2012a) that measures the income/value added in a country that is generated by final demand in other countries. Johnson and Noguera refer to the ratio of value added exports to gross exports as the VAX ratio $\left(V A X^{\$} / X^{\$}\right)$, and they interpret it as a measure of vertical specialization. The more a country can rely on domestic intermediate inputs and the more it can rely on domestic raw materials, the higher will be its VAX ratio. Large countries tend to have higher VAX ratios, and the VAX ratio in services and agriculture tends to be higher than in manufacturing. Figure 1 shows the percentage point change in the VAX ratio by country from 1995 to 2007, the year before the onset of the financial crisis and the

\footnotetext{
${ }^{1}$ See Davidson and Matusz (2009) for a collection of trade models models that incorporate frictional unemployment. See Helpman and Itskhoki (2015) for additional references to trade models that merge labor market frictions with heterogeneous firms.
} 
ensuing collapse of trade. ${ }^{2}$ Germany's VAX ratio declined by 9.6 percentage points; that is, the economy generated 9.6 cent less domestic wage and profit income per euro export revenue in 2007 than in 1995. Germany's production for the foreign market relies to an increasing extent on imported inputs. Ignoring tiny and financialized Luxembourg, the largest declines in the VAX ratio can be observed in Eastern European economies that joined the World Trade Organization in 1995 and started to integrate into the regional production chain around Germany well before the Eastern enlargement of the European Union in 2004 and 2007 (Czech Republic, Hungary, Poland, and Slovakia). ${ }^{3}$

The complement to value added exports is the income/value added in a country that is generated by own or domestic final demand $\left(D D I^{\$}\right)$. Domestic demandgenerated income and value added exports add up to GDP, that is, $Y^{\$}=D D I^{\$}+$ $V A X^{\$}$. The ratio of domestic demand-generated income $D D I^{\$}$ to domestic demand $A^{\$}$, the $D D I$ ratio $\left(D D I^{\$} / A^{\$}\right)$, can be interpreted as a measure of a country's capacity to stimulate domestic economic activity through domestic sources of final demand. Open economies tend to have low DDI ratios, and closed economies tend to have high DDI ratios. In 2011 (the latest available data point) Ireland recorded a DDI ratio of 53 percent; Germany recorded a DDI ratio of 72 percent; and France, Greece, Italy, Spain, and Portugal recorded DDI ratios between 78 and 83 percent. Figure 1 shows the percentage point change in the DDI ratio by country from 1995 to 2007. Once again, Eastern European economies populate the top of the list. Germany's DDI ratio declined by 9.4 percentage points; that is, the economy generated 9.4 cent less domestic wage and profit income per euro domestic demand in 2007 than in 1995. The part of Germany's production that meets domestic consumption and investment demand relies to an increasing extent on imported inputs. The 9.4-percentage-point decline is exceptional among the large European economies. Although Spain comes close (5.9 percentage points), the pace of international supply chain fragmentation was considerably lower in France, Italy, and the UK.

The decline in Germany's DDI ratio is quantitatively more significant than the decline in the VAX ratio. In 2007, Germany's domestic demand, worth 2330 billion euros, generated 1679 billion euros in domestic income; if the DDI ratio had remained at the level of 1995, hypothetically Germany's GDP would have been 220 billion euros higher. In the same year, Germany's gross exports, worth 1081 billion euros, generated 792 billion euros in domestic income; if the VAX ratio had remained at the level of 1995, Germany's GDP would have been 104 billion euros higher. ${ }^{4}$

\footnotetext{
${ }^{2}$ Stehrer (2013) reports VAX ratios for 40 countries for every year from 1995-2011. DDI ratios can be computed from the results reported in Foster et al. (2013). The two sources overlap for the selection of countries (EU27) and the choice of the time period (1995-2007) that is shown in Fig. 1. The change in the VAX ratio in Germany's sick man period 1995-2005 is similar to the change in 1995-2007.

${ }^{3}$ The term global value chain fails to capture the regional character of value chains, which tend to link production facilities in geographically proximate countries to one another (Johnson and Noguera 2012c; Elms and Low 2013).

${ }^{4}$ The 2007 DDI ratio times 2007 domestic demand gives actual 2007 DDI. The 1995 DDI ratio times 2007 domestic demand gives the hypothetical 2007 DDI. The difference between actual and hypothetical DDI is the hypothetical GDP loss of 220 billion euros. The 104 billion euro GDP loss that is attributable to the decline the VAX ratio was computed in analogous manner.
} 


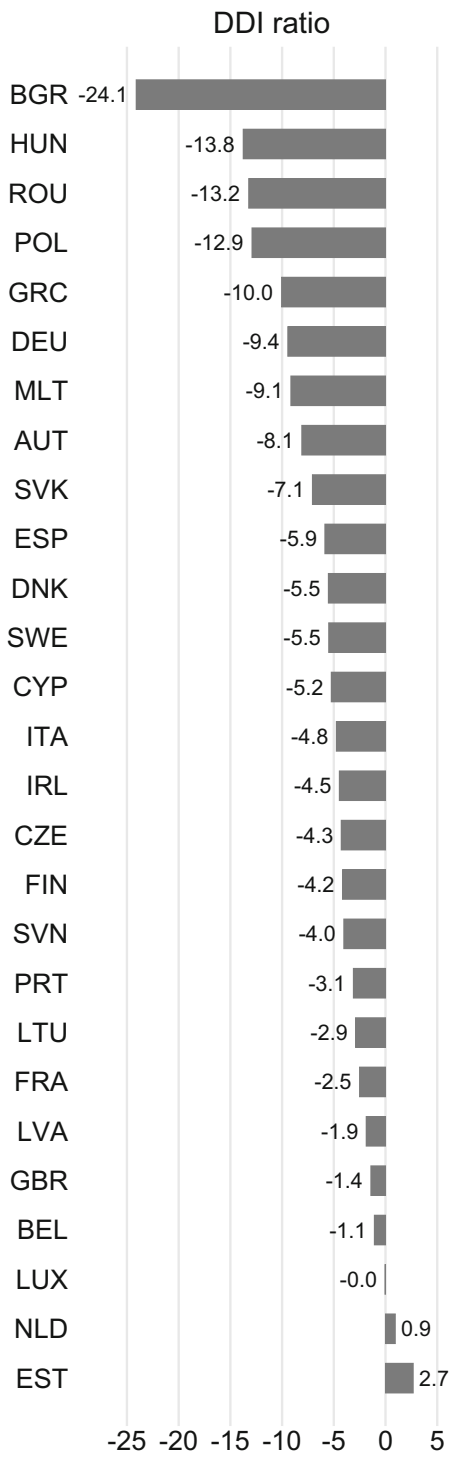

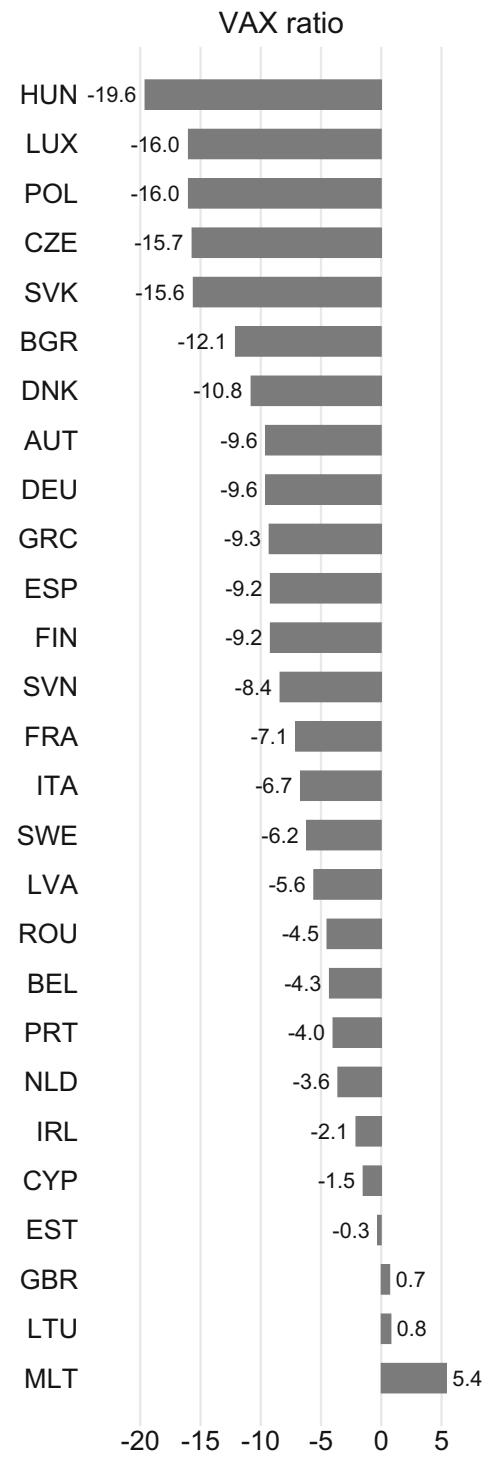

Percentage point change 1995-2007

Fig. 1 Change in DDI and VAX ratios in the European Union (EU27), 1995-2007. The VAX ratio is value added exports divided by gross exports, as reported in Stehrer (2013). The DDI ratio is domestic demandgenerated income divided by domestic demand. Foster et al. (2013) report DDI as a share of GDP, that is, $D D I^{\$} / Y^{\$}$. Multiplication by GDP gives DDI itself, and division of DDI by domestic demand gives the DDI ratios. The DDI ratios are computed using national accounts data from AMECO (2017)

The DDI ratio and the VAX ratio should be regarded as aggregate summary measures rather than structural parameters, and they are certainly not independent of domestic and foreign demand. It can be argued that foreign demand for Germany's 
products was strong in part because German firms readily made use of the then new opportunities in Central and Eastern Europe, and the VAX ratio reflects the international fragmentation of supply chains that allowed German firms to reduce costs and improve international competitiveness. Thus one might say that demand for German products was high because the VAX ratio declined, and the value of exports in 2007 would have been lower if the VAX ratio had not declined. This article argues that domestic demand in Germany was weak in part because German firms moved parts of their production chain abroad. Thus one might say that domestic demand in 2007 would have been higher if the DDI and the VAX ratios had not declined. This reasoning makes clear that the hypothetical GDP losses described above are no more than illustrations of the quantitative significance of the observed changes in the DDI and VAX ratios. These aggregate summary measures reflect the increasing reliance in the production of Germany's exports and the satisfaction of Germany's domestic consumption and investment demand on inputs imported from abroad. The international fragmentation of production was occurring at a more rapid pace in Germany than elsewhere in Europe (with the exception of small economies in the East). Moreover, from the 1990s onward it was occurring at a more rapid pace than in the preceding decades. (Germany's VAX ratio was declining since the 1970s and the decline accelerated in the 1990s; see Johnson and Noguera 2012b)

The effect of offshoring on Germany's aggregate employment rarely has been an object of econometric study. In accordance with established modeling traditions, most econometric studies estimate the effect of offshoring on skill premia and within-country inequality. For a survey, see Harrison et al. (2011). Winkler (2010) uses a panel dataset that comprises annual observations on 35 German manufacturing industries from 1995-2006 to estimate the effect of offshoring on German manufacturing employment. Winkler finds that services offshoring did reduce manufacturing employment by 2.6 percent over the whole sample period. The result can be explained, in Winkler's view, by the rigidity of the German labor market that prevented the re-absorption of displaced workers. ${ }^{5}$

There are econometric studies that take the individual worker as the unit of analysis and that point to heightened job insecurity, but it is not possible to predict aggregate job losses on this basis. Geishecker (2008), Bachmann and Braun (2011), and Görg and Görlich (2015) estimate the effect of offshoring on the risk of becoming unemployed in Germany, using either longitudinal survey data or the notifications made by employers to the social security agencies. The results are mixed and appear to differ by skill class. Offshoring appears to have led to an increase in the unemployment risk of low-skilled workers in Germany.

\footnotetext{
${ }^{5}$ Amiti and Wei (2005, 2009), Milberg and Winkler (2013, ch.5), and Wright (2014) estimate the effect of offshoring on employment in the United Kingdom and the United States, using similar data sets, that is, panels with national industry-level observations at annual frequency.
} 


\section{The model}

The Keynes-Kalecki open-economy models in Blecker $(1989,2011)$ feature labor as the only variable factor of production and rest on what can be labeled the "consumer approach" to import demand - no imports are required for domestic production, all imports are treated as final goods. ${ }^{6}$ The models in Bhaduri and Marglin (1990), Taylor (2004, ch.7) feature imported raw materials and/or intermediate goods as a second factor of production besides labor. ${ }^{7}$ In this tradition, the import demand function is conceived as a factor demand function, and domestic activities add value before imported intermediates are put to their final use. It should be noted that even imported consumption goods do not enter consumption directly, but are imported by firms and sold to consumers. Accordingly, the "producer approach" to import demand treats all imports, including consumption goods, as inputs to domestic production. It goes back at least to Burgess (1974), who derives import demand functions from production theory. ${ }^{8}$ Kennedy and Thirlwall (1979) effectively view imports as inputs to domestic production as well, and functionally relate imports to domestic expenditure rather than income.

To see the implications, it is helpful to start with the gross output identity $G O^{\$}=A^{\$}+X^{\$}$. The dollar superscript indicates that the variables are nominal magnitudes expressed in domestic currency. Differences between purchaser's prices and basic prices are ignored. On the expenditure side, gross output is composed of domestic expenditure on domestic output (consumption and investment are aggregated into $A^{\$}=C^{\$}+I^{\$}$ ), and foreign expenditure on domestic output (exports $X^{\$}$ ). On the production side, gross output is the sum of value added and intermediate consumption $G O^{\$}=Y^{\$}+I C^{\$}$. The model below abstracts from domestic intermediate inputs, and treats all imports $M^{\$}$ as inputs to domestic production. In this case, gross output equals value added plus imports $G O^{\$}=Y^{\$}+M^{\$}$. Value added equals total expenditure (equal to gross output) minus imports $Y^{\$}=A^{\$}+X^{\$}-M^{\$}$, the national income identity. The wage bill $W B^{\$}$ and profits $F^{\$}$ make up domestic income $Y^{\$}=W B^{\$}+F^{\$}$.

The model is best explained with reference to the complete equation system:

$$
\begin{aligned}
Y & =A+X-R \cdot M \\
A & =a\left(W B, F, \alpha^{a}\right), \quad a_{W B}>a_{F}>0, a_{\alpha^{a}}=1 \\
X & =x\left(R, \alpha^{x}\right), \quad x_{R}>0, a_{\alpha^{x}}=1 \\
M & =m \cdot(A+X)
\end{aligned}
$$

\footnotetext{
${ }^{6}$ von Arnim et al. (2014) present the two-country extension of this type of model.

${ }^{7}$ Rezai (2015) presents the two-country extension of this type of model.

${ }^{8}$ Kohli (1991) deals at length with production theory and import demand. Travel for leisure, recorded in the balance of payments on the services account, possibly is the only good that can be said to enter final consumption directly. Yet any vacation activity more broadly conceived contains domestic value added as well, e.g. expenses for domestic transportation and travel agents.
} 


$$
\begin{aligned}
N & =n \cdot(A+X) \\
P & =U C /(1-\pi) \\
U C & =W \cdot n+P^{M} \cdot m \\
R & =P^{M} / P \\
W B & =W \cdot N / P \\
F & =Y-W B \\
\psi & =1-\pi-R \cdot m
\end{aligned}
$$

Equation 1 is the equilibrium condition. If inventories were counted in $A$, the equation would be the national income identity in real terms. Domestic expenditure on domestic output $(A=C+I)$ and foreign expenditure on domestic output (exports, $X)$ generate income at home; domestic expenditure on foreign output (imports, $M$ ) generates income abroad. The macroeconomic quantities in Eq. 1 are measured in terms of domestic output, that is, money values are converted into real magnitudes through division by $P$, the price of domestic output. The domestic-currency price of imports $P^{M}$ divided by $P$ is the real exchange rate $R$.

In Keynes-Kalecki models of growth and distribution, the macroeconomic quantities saving and investment are typically scaled by the capital stock. This convention is most convenient in dynamic models designed to illuminate questions related to longrun growth, but does not add insight nor simplify algebra in the static model presented here. $Y$ denotes the level of income, $A$ the level of domestic expenditure, and so on.

While it is customary to specify a saving function $S=s(W B, F)$, where $S$ denotes saving, $F$ profits, and $W B$ the wage bill, one can equivalently specify a consumption function $C=c(W B, F)$ the partial derivatives of which are one minus the propensity to save: $c_{W B}=1-s_{W B}$ and $c_{F}=1-s_{F}$ (subscripts denote partial derivatives). The assumption that the propensity to save out of wages is smaller than the propensity to save out of profits amounts to $c_{W B}>c_{F}$. Combining the consumption function with an investment function gives a domestic expenditure function. Suppose investment $I$ depends on current profits $F$ and on the exogenously given state of long-term expectations $\alpha^{a}$. This assumption leads to the expenditure function in Eq. 2: $a\left(W B, F, \alpha^{a}\right)=c(W B, F)+i\left(\alpha^{a}, F\right)$. The partial derivative $a_{W B}$ can be interpreted as the marginal propensity to consume out of wage income and $a_{F}$ as the marginal propensity to consume and invest out of profit income. It is assumed that $a_{W B}>a_{F} . \alpha^{a}$ is an exogenous shift variable; without loss of generality the partial derivative $a_{\alpha^{a}}$ can be set to one.

The inequality $a_{W B}>a_{F}$ is an assumption about the behavior of domestic demand, technically about the relative magnitude of two structural parameters. This assumption should be distinguished from the notion of a "wage-led demand regime", which refers to a Keynes-Kalecki model's reduced form. A model economy is said to exhibit wage-led demand when the equilibrium level of output or capacity utilization is inversely related to the profit share (e.g. Lavoie and Stockhammer 2013). In general, the profit share can be treated as an endogenous variable or as an exogenous variable. If the profit share is treated an an endogenous variable, the relation between equilibrium output and equilibrium profit share will, in general, depend 
on the source of the exogenous variation considered. In the system (1)-(11), if the markup is endogenous, the price is exogenous, and the exogenous variation considered is an increase in money wages, then the model economy will exhibit wage-led demand by virtue of assumption $a_{W B}>a_{F}$. A large body of empirical literature uses varied econometric methods to assess whether the wage-led demand regime, or, alternatively, the profit-led demand regime, best characterizes modern economies. The literature produces mixed econometric results that do not permit the drawing of universal conclusions. ${ }^{9}$ In the light of the prima facie evidence from Germany's sick man period - the co-existence of low growth and a falling wage share - this article will proceed with the assumption $a_{W B}>a_{F}$.

Equation 3 states the export demand function $x(\cdot)$, which is one-time continuously differentiable in every argument. The real exchange rate is so defined that rising $R$ represents depreciation and declining $R$ represents appreciation, thus $x_{R}>0$. The model embodies the assumption that non-price competitiveness factors such as process and product innovations and product quality upgrades are largely independent of offshoring (as the primary objective of offshoring is cost cutting and the real exchange rate as a measure of price competitiveness does appear as an endogenous variable in the model). The variable $\alpha^{x}$ is an exogenous shift variable that can be used to study the effects of a generic export shock (e.g. a foreign expenditure boom or an improvement in non-price competitiveness).

Equations 4 and 5 can be interpreted as conditional factor demand functions derived by cost minimization from a Leontief technology. Domestic production is subject to constant returns to scale and requires imports $M$ and domestic labor $N$ in fixed proportions; $m$ is the unit import requirement and $n$ is the unit labor requirement. This assumption about the economy's production technology is routinely made in Keynes-Kalecki models, where complexities arising from the presence of overhead labor are assumed away and direct unit costs are postulated to be constant up to full-capacity output (e.g. Bhaduri and Marglin 1990). The model abstracts from heterogenous import and labor intensities: production for the foreign market $X$ is subject to the same factor requirements as production for the domestic market $A$. In reality, the import intensity varies considerably across the demand categories: exports and investment expenditure tend to induce the largest quantity of imports, followed by private consumption expenditure (Kennedy and Thirlwall 1979; Bussière et al. 2013). If the model were to be confronted with data, differential import requirements would need to be incorporated; to study the theoretical implications of changes in the average factor requirements, this type of heterogeneity might not be necessary.

Equation 6 says that the price of domestic output is set as a markup $\tau$ on unit costs $U C$. The markup reflects the degree of monopoly (Kalecki 1954). For mathematical convenience, the share of profits in gross output $\pi$ enters the equation instead of the markup. The relation between the two variables is $\tau=\pi /(1-\pi) \Leftrightarrow \pi=$ $\tau /(1+\tau)$, so an equivalent formulation of the price equation is $P=(1+\tau) \cdot U C$.

\footnotetext{
${ }^{9}$ Lavoie (2014, ch.6) reviews the empirical and theoretical literature on wage-led and profit-led demand regimes. The interested reader may also consult the contributions by Naastepad and Storm (2007), Kiefer and Rada (2015), Blecker (2016), and Onaran and Obst (2016), and the references therein.
} 
Equation 7 gives unit costs as the sum of unit labor costs (the money wage $W$ times the unit labor requirement $n$ ) and unit import costs (the domestic-currency price of imports $P^{M}$ times the unit import requirement $m$ ). From the Leontief technology it follows that unit costs are constant and coincide with marginal costs.

Equation 8 defines the real exchange rate. It is assumed that the country's trade flows do not influence its nominal exchange rate. The assumption is justified if the exchange rate is an asset price determined in financial markets, and if the model represents a member of the European Monetary Union the influence of which on the euro exchange rate can be neglected. The nominal exchange rate $S$ and the foreigncurrency price of imports are determined outside the model, so the domestic-currency price of imports $P^{M}$ is exogenous as well.

Equations 9 and 10 measure the wage bill $W B$ and profits $F$ in terms of the domestic good, that is, money incomes are divided by $P$. Equation 10 says that income/ value added is composed of the wage bill and profits.

Equations 6 and 7 can be combined to give $P \cdot(1-\pi)=W \cdot n+P^{M} \cdot m$. Divide by $P$ and use the definition of the real exchange rate to arrive at a decomposition of gross output $1=\pi+W \cdot n / P+R \cdot m$. The term in the middle is the share of wages in gross output $W \cdot n / P=W B /(A+X)$. It will be denoted by $\psi$ (11). The profit share, the wage share, and the import share add up to one. Output is composed of profits, wages, and import expenditure:

$$
A+X=F+W B+R \cdot M=(\pi+\psi+R \cdot m) \cdot(A+X) .
$$

There are 11 equations for the 18 variables listed in Table 1 . If 11 variables are treated as endogenous and seven as exogenous, the system can be solved in principle.

Table 1 List of variables

\begin{tabular}{ll}
\hline$Y$ & Real income \\
$A$ & Real domestic expenditure \\
$M$ & Real imports \\
$N$ & Labor input/employment \\
$X$ & Real exports \\
$P$ & Price of domestic output \\
$U C$ & Unit costs \\
$W B$ & Real wage bill \\
$F$ & Real profits \\
$R$ & Real exchange rate \\
$m$ & Unit import requirement \\
$n$ & Unit labor requirement \\
$W$ & Money wage \\
$P^{M}$ & Domestic-currency price of imports \\
$\pi$ & Share of profits in gross output \\
$\psi$ & Share of wages in gross output \\
$\alpha^{a}$ & Autonomous domestic expenditure \\
$\alpha^{x}$ & Autonomous exports \\
\hline & \\
\hline &
\end{tabular}


The convention in the pure theory of trade is to study closures that treat goods prices, money wages, and the exchange rate as endogenous variables; in equilibrium, these variables would then take on values that satisfy the full-employment and balancedtrade conditions. This article studies Keynesian closures in the sense that the money wage and the exchange rate are treated as exogenous variables and employment as an endogenous variable, which may be at the full-employment level or not. Balanced trade is a possible outcome of the model, but it will not be an object of study.

\subsection{Labor-saving import-using technical change}

Firms adopt a new technique of production if it is viable. A technique is viable if it increases the profit rate at the prevailing set of factor prices. ${ }^{10}$ In this model, the domestic capital stock is treated as given; offshoring adds to the capital stock abroad, in the case of greenfield investment, or involves a transfer of claims over existing productive assets. In either case, we shall assume that offshoring is profitable if it increases the markup at the prevailing set of factor prices. Implicit is the assumption that fixed costs do not drive a wedge between the change in the markup and the change in the profit rate. In other words, if the markup increases, so does the profit rate.

Firms with below-average unit costs are able to set above-average markups, earning them superprofits. Given factor prices, the profit motive induces firms to introduce new techniques of production that economize on the factors of production. Let the pair $\left[n^{1}, m^{1}\right]$ describe a production technique. It is clear that a new technique $\left[n^{\prime}, m^{\prime}\right]$ that saves labor and saves imports, $n^{\prime}=n^{1}+\Delta n<n^{1}$ and $m^{\prime}=m^{1}+\Delta m<$ $m^{1}$, generates superprofits. A new technique $\left[n^{2}, m^{2}\right]$ that saves labor and uses imports, $n^{2}=n^{1}+\Delta n<n^{1}$ and $m^{2}=m^{1}+\Delta m>m^{1}$, generates superprofits only if the new unit costs are lower than the old:

$$
\begin{aligned}
U C^{2} & <U C^{1} \\
W \cdot n^{2}+P^{M} \cdot m^{2} & <W \cdot n^{1}+P^{M} \cdot m^{1} \\
W \cdot \Delta n+P^{m} \cdot \Delta m & <0 .
\end{aligned}
$$

The new technique is viable if it saves more labor costs than it adds import costs. The condition could also be expressed in terms of factor shares and rates of change of factor requirements, that is, $s^{n} \cdot \Delta n / n+s^{m} \cdot \Delta m / m<0$, where $s^{n}=W \cdot n / U C$ and $s^{m}=P^{m} \cdot m / U C$. A one-percent reduction in the unit labor requirement obviously saves more labor costs if the labor cost share is high and the associated increase in the unit import requirement is small. Details aside, the key takeaway is the idea that offshoring is viable only if it leads to a fall in unit costs. The viability condition (13) will allow us to determine the qualitative behavior of endogenous variables in response to offshoring.

We will study the consequences of a simultaneous exogenous decrease in $n$ and increase in $m$. The rationale for the postulate of increasing labor productivity follows from the well-established theoretical result that offshoring increases the

\footnotetext{
${ }^{10}$ For a discussion of viability and biased technical change, see Foley and Michl (1999).
} 
productivity of labor tasks that continue to be performed at home; in this respect, offshoring is analogous to factor-augmenting technological change (Grossman and Rossi-Hansberg 2008). It is in the nature of offshoring that the fruits of foreign labor are then imported for use as inputs to the domestic production process - hence the import content of output increases, that is, $m$ increases. A quick look at the Eqs. 4, 5, 7, and 11 reveals that the direct effect of labor-saving import-using technical change is higher import expenditure, lower employment, lower unit costs (given the viability condition), and a reduced wage share. We are interested in the total effects, which obviously depend on the interactions between all the endogenous variables in the complete system (1)-(11).

In order to establish production facilities abroad, the offshoring firm will rely on domestic and foreign suppliers for the procurement of equipment and know-how. The efficiency-seeking investment that is necessary to introduce new techniques of production constitutes effective demand for domestic output and/or foreign output - the offshoring process itself generates income and expenditure at home and/or abroad. The model abstracts from the demand-generating effects of foreign direct investment on the grounds that these recede once the new production structure is in place. The temporary investment stimulus changes the factor requirements; to study the consequences, it is sufficient to postulate that $n$ declines and $m$ rises and work out the implications with respect to the new equilibrium point.

\subsection{Two alternative closures: constant-price and constant-markup}

Offshoring reduces unit costs. The behavior of prices in response to a reduction in unit costs needs to be specified. Recall that the price equation is $P=(1+\tau) \cdot U C$, and $\tau$ reflects the degree of monopoly. The Kaleckian vision maintains that the degree of monopoly is exogenously determined by the institutional environment, which is characterized by features such as the concentration of industry, the degree of product differentiation, and the power of labor unions. Under the assumption that the influence of offshoring on the institutional environment can be neglected and $\tau$ remains precisely constant, prices would fall in proportion to unit costs. ${ }^{11}$

Offshoring may, however, change the institutional environment. For instance, Rodrik (1997) argues that as international economic integration proceeds and international trade and investment flows increase, firms can more easily substitute domestic workers with foreign workers and imports - labor demand becomes more elastic. The increased elasticity of labor demand reduces the bargaining power of workers, which would cause $\tau$ to rise as a consequence of offshoring. Even the option to import goods and offshore production might be sufficient to strengthen the bargaining

\footnotetext{
${ }^{11}$ A profit-maximizing firm under conditions of monopolistic competition would set the price as $P=$ $M C /(1+1 / \varepsilon)$, where $M C$ denotes marginal costs and $\varepsilon$ is the price elasticity of demand for the firm's product. If average and marginal costs were the same, that is, if there were no fixed costs and marginal costs were constant, there would exist a proportional relation between average unit costs and price.
} 
power of firms relative to workers, regardless of whether imports and foreign direct investment flows actually materialize. This idea travels under the name "threat effects" (e.g. Dube and Reddy 2014).

Starting in the 1990s, many German companies were indeed threatening to relocate production from high-wage West Germany to low-wage East Germany and even lower-wage Central and Eastern Europe in order to gain concessions from labor unions (e.g. Ahlers et al. 2007; Dustmann et al. 2014; Krzywdzinski 2014). So-called "opening clauses" and "employment protection agreements" began to be introduced, which allow individual firms and plants to deviate in terms of pay and working time from the standards set by the industry-wide collective agreements. The accessibility of low-wage labor in Central and Eastern Europe shifted bargaining power from workers to firms.

Milberg and Winkler (2013) report that multinational firms in advanced economies absorbed the cost advantages gained by offshoring in the form of higher markups. The additional profits, the authors argue, were not retained and used for the financing of real investment, which would have constituted effective demand and enhanced the economy's productive capacity, but rather the profits were channeled to financial markets, where they contributed to asset price inflation. In this manner, Milberg and Winkler link offshoring and financialization, and they contend that offshoring helps explain the increase in profit shares and the decline in investment shares observed in many advanced economies.

While the Eqs. 1 through 11 do not represent a wage bargaining process, the above considerations suggest that it may be worthwhile to study two different closures:

Constant-price closure The price $P$ is treated as an exogenous variable and held constant, and the markup $\tau$ rises endogenously in response to offshoring. Firms absorb the cost advantage entirely, and offshoring fails to have any impact on international competitiveness.

Constant-markup closure The markup $\tau$ is treated as an exogenous variable and held constant, and the price $P$ falls endogenously in proportion to unit costs. Offshoring improves international competitiveness.

\section{Comparative static results}

The principal object of interest is the qualitative behavior of endogenous variables, in particular the behavior of domestic employment $N$, in response to offshoring. Under what conditions does employment rise and under what conditions does it fall? Mathematically we are interested in the sign of the total differential of equilibrium employment in the neighborhood of the equilibrium point, that is, $d N^{e}=$ $\frac{\partial N^{e}}{\partial n} \cdot \Delta n+\frac{\partial N^{e}}{\partial m} \cdot \Delta m$. The changes in the factor requirements $(\Delta m$ and $\Delta m)$ are exogenously given and the partial derivatives of equilibrium employment $\left(\frac{\partial N^{e}}{\partial n}\right.$ and $\left.\frac{\partial N^{e}}{\partial m}\right)$ can be found by means of the comparative static method (e.g. Gandolfo 2010, ch.20). The Appendix A derives the results in glorious detail and demonstrates that the equilibrium is dynamically stable. This section states and discusses the model's results. 


\subsection{Offshoring under the constant-price closure}

It is helpful to introduce some key terms before discussing the effect of offshoring on domestic employment. The empirical literature on offshoring and labor demand refers to the substitution effect, the productivity effect, and the scale effect (e.g. Amiti and Wei 2009). The substitution effect is the response of labor demand to changes in factor prices; it does not surface when production is based on the Leontief technology. The productivity effect arises because offshoring enables firms to produce a given level of output with less domestic labor. The scale effect arises because offshoring may influence the quantity sold: offshoring reduces costs, lower costs enable firms to set lower prices, and lower prices raise demand for output. Since it is assumed in this section that the sales price remains constant, there should be no scale effect. In contrast, however, to the empirical literature, which estimates labor demand functions at the industry level, the demand-constrained macro model gives rise to scale effects even as the price remains constant. The replacement of domestic workers by imported inputs reduces domestic labor income per unit of output, and the increase in the markup involves a redistribution away from wages and towards profits. Both factors tend to weaken domestic demand. The next section shows that, in this macro model, the scale effect is the sum of the expenditure effect (the domestic demand-induced change in employment) and the competitiveness effect (the foreign demand-induced change in employment). Under the constant-price closure discussed in this section, there is no competitiveness effect, and offshoring causes domestic expenditure and labor demand to fall.

The total differential of equilibrium employment $N^{e}$ is

$$
\begin{aligned}
& \text { Expenditure effect (-) } \\
& d N^{e}=\underbrace{\Delta n \cdot\left(A^{e}+X^{e}\right)}_{\text {Productivity effect }(-)} \quad \overbrace{\bar{n} \cdot d A^{e}}<0 .
\end{aligned}
$$

The first term, $\Delta n \cdot\left(A^{e}+X^{e}\right)<0$, arises because less labor is required per unit of output. This productivity effect is well known in short-run Keynes-Kalecki models, where an increase in labor productivity generates technological unemployment unless there is a commensurate increase in the autonomous components of expenditure (Lavoie 2014, pp. 296-298). The second term, $\bar{n} \cdot d A^{e}<0$, represents a decline in employment in proportion to an induced fall in domestic expenditure, and this expenditure effect adds to technological unemployment. (That domestic expenditure does indeed fall, $d A^{e}<0$, will be shown further below.) Overall, offshoring tends to generate unemployment because less labor is required per unit of output and because it introduces a deficiency of domestic demand.

The left panel in Fig. 2 illustrates the effect of offshoring on employment under the constant-price closure. The top graph shows two relations between employment $N$ and gross output $A+X$, which are linear because the economy's production technology is Leontief. Labor demand as a function of output is $n^{1} \cdot(A+X)$ before offshoring and $n^{2} \cdot(A+X)$ after. Since offshoring reduces the unit labor requirement, $n^{2}<n^{1}$, a given level of output generates less employment. The bottom graph shows relations between unit costs $U C$ and output $A+X$. The two horizontal lines represent (7), which defines unit costs in terms of exogenous variables and parameters, 
Constant price, endogenous markup

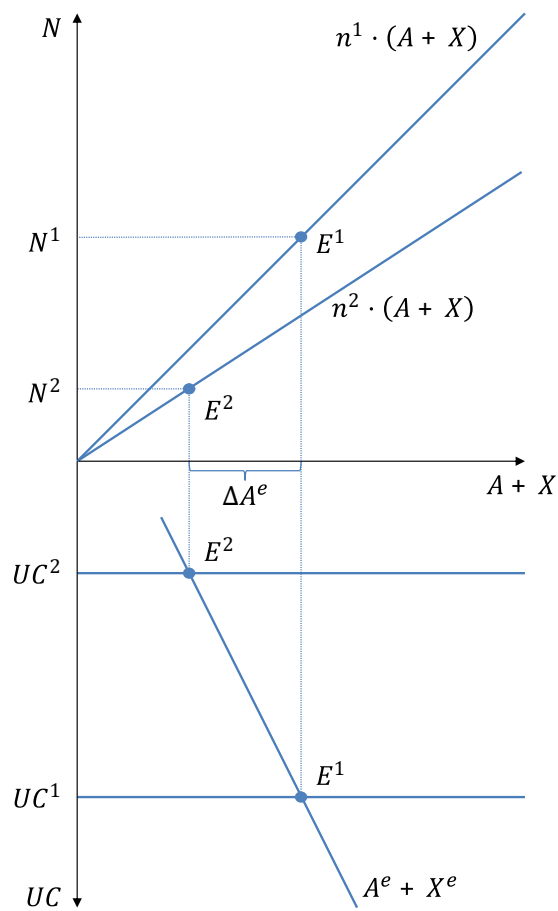

Constant markup, endogenous price

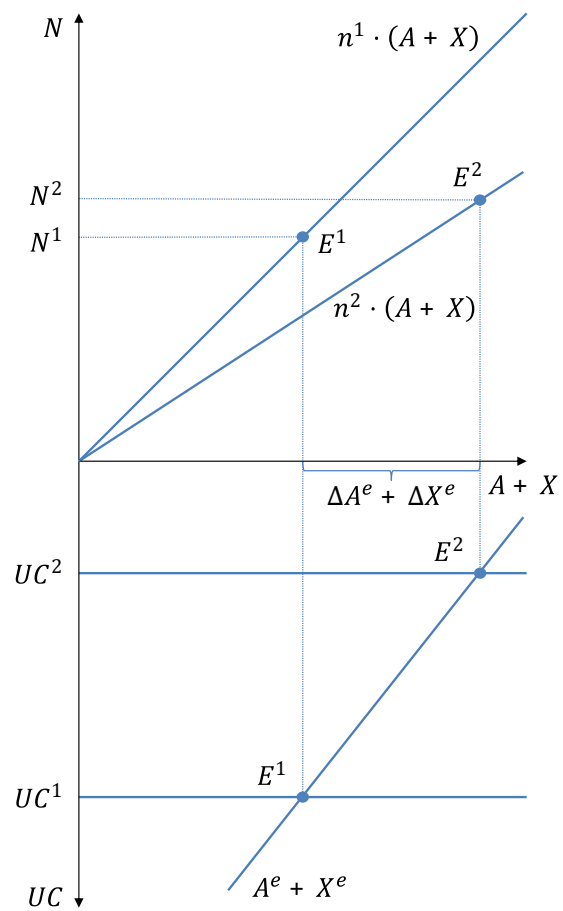

Fig. 2 The effect of offshoring on domestic employment under two different closures. $N$ denotes employment, $A+X$ gross output/total expenditure (domestic demand plus exports), and $U C$ unit costs. The lines labeled $A^{e}+X^{e}$ express the relation between equilibrium output and unit costs. The superscript 1 indicates the initial state before offshoring and the superscript 2 the state after offshoring. The economy moves from the equilibrium point $E^{1}$ to $E^{2}$. Detailed explanations are given in Sections 4.1 and 4.2

before offshoring $\left(U C^{1}\right)$ and after $\left(U C^{2}\right)$. The lines are horizontal because the economy's production technology is Leontief. The sloped line represents the relation between equilibrium output $A^{e}+X^{e}$ and unit costs, which need not be linear, but is drawn that way. Under the constant-price closure, offshoring fails to improve international competitiveness and exports remain constant $\left(\triangle X^{e}=0\right)$; there is a positive relation between unit costs and equilibrium output because offshoring reduces unit costs while at the same time it reduces labor income and weakens domestic demand $\left(\triangle A^{e}<0\right)$. The economy moves from the initial equilibrium $E^{1}$ to the new equilibrium $E^{2}$. The combined force of higher labor productivity and lower domestic demand creates unemployment.

The fall in domestic expenditure induced by offshoring appears as a total differential in Eq. 14. This differential is

$$
\begin{aligned}
d A^{e} & =\kappa \cdot\left(A^{e}+X^{e}\right) \cdot\left[a_{W B} \cdot d \psi^{e}+a_{F} \cdot d \pi^{e}\right] \\
& =\kappa \cdot\left(A^{e}+X^{e}\right) \cdot\left[\Delta n \cdot \frac{\bar{W}}{\bar{P}} \cdot\left(a_{W B}-a_{F}\right)-\Delta m \cdot a_{F} \cdot R^{e}\right]<0
\end{aligned}
$$


where $\kappa$ is the open-economy multiplier associated with this model: ${ }^{12}$

$$
\kappa \equiv 1 /\left(1-a_{W B} \cdot \psi^{e}-a_{F} \cdot \pi^{e}\right) .
$$

Consider the terms in the square bracket in Eq. 15. Labor productivity increases, hence unit costs fall, and the markup rises at the expense of the wage share; in combination with differential spending propensities, this change in the functional income distribution weakens domestic expenditure: $\Delta n \cdot\left(a_{W B}-a_{F}\right) \cdot \bar{W} / \bar{P}<0$. The last term, $-\Delta m \cdot a_{F} \cdot R^{e}<0$, arises because producers require more imports per unit of output. This implies a loss of profit income, which further weakens domestic expenditure. Overall, domestic expenditure falls because income shifts from high-spending domestic wage earners to low-spending domestic profit earners and foreigners. ${ }^{13}$

\subsection{Offshoring under the constant-markup closure}

This section studies the effect of offshoring on domestic employment under the assumption that lower costs are completely passed on to end-users. The improvement in international competitiveness stimulates exports. If the foreign demand injection is sufficiently large, it may overturn the expenditure-reducing effects that arise from the displacement of domestic workers and the associated loss of wage income. Labor demand may rise or fall in response to offshoring, depending crucially on the price elasticity of export demand.

The total differential of equilibrium employment $N^{e}$ is

$$
d N^{e}=\underbrace{\Delta n \cdot\left(A^{e}+X^{e}\right)}_{\text {Productivity effect }(-)} \underbrace{+\bar{n} \cdot\left(d A^{e}+d X^{e}\right)}_{\text {Scale effect }( \pm)} \gtreqless 0 .
$$

The productivity effect, which is the same as in the previous section, tends to reduce labor demand. In contrast to the constant-price closure, export demand increases as a result of improved international competitiveness. Higher production for the foreign market requires additional labor input - the competitiveness effect $\bar{n} \cdot d X^{e}>0$ tends to raise labor demand. A high price elasticity of export demand will produce a large competitiveness effect (discussed below). The expenditure effect $\bar{n} \cdot d A^{e} \gtreqless 0$ from the previous section makes a reappearance, but this time it may be greater than zero. On the one hand, the lower wage income induces a fall in domestic expenditure as it did under the constant-price closure, while on the other hand, the additional production of exports generates domestic wage and profit income, which tends to stimulate domestic demand. If exports increased by a sufficiently large amount, domestic demand would rise in response to offshoring and add to the injection of foreign demand.

\footnotetext{
${ }^{12}$ If the spending propensities are the same across income types, $a_{W B}=a_{F}=a_{Y}$, the analogies to a standard open-economy multiplier (Harrod 1933; Machlup 1943) become obvious: $\kappa^{\left\{a_{W B}=a_{F}\right\}}=$ $1 /\left(1-a_{Y}+a_{Y} \cdot R^{e} \cdot \bar{m}\right)$.

${ }^{13}$ Recall that domestic demand is assumed to be wage-led; this assumption is essential for the above result.
} 
Again, the price elasticity of exports is key. The competitiveness effect and the expenditure effect together make up the scale effect, which is ambiguous in sign because the expenditure effect is ambiguous in sign.

The right panel in Fig. 2 illustrates the effect of offshoring on employment under the constant-markup closure. The labor demand functions in the top graph are the same as before. The two horizontal lines in the bottom graph that represent unit costs before and after offshoring carry over unaltered as well. However, the relation between equilibrium output and unit costs is different, and the model's assumptions do not yield unambiguous results in regard to its slope. It is drawn as a line that associates low values of unit costs with high values of equilibrium output, so output is higher $\left(\triangle A^{e}+\triangle X^{e}>0\right)$ at the new equilibrium point $E^{2}$. In this particular case, as it is drawn, output is so much higher that equilibrium labor demand is higher as well $\left(N^{2}>N^{1}\right)$. In other words, the positive scale effect is larger in magnitude than the negative productivity effect, hence offshoring increases labor demand. It is possible, although the figure does not show this case, that equilibrium labor demand falls even as equilibrium output rises, namely when the negative productivity effect dominates the positive scale effect. Yet another case, not shown in the figure either, occurs when the scale effect is negative, that is, when the induced weakening of domestic demand dominates the strengthening of export demand. The figure would show a positive relation between unit costs and equilibrium output (as under the constant-price closure in the left panel), and both the productivity effect and the scale effect would reduce labor demand. Overall, the constant-markup closure yields ambiguous results.

Consider the total differential of the equilibrium level of domestic expenditure, which is

$$
d A^{e}=\kappa \cdot\left[\left(a_{W B} \cdot \psi^{e}+a_{F} \cdot \pi^{e}\right) \cdot d X^{e}+a_{W B} \cdot\left(A^{e}+X^{e}\right) \cdot d \psi^{e}\right] \gtreqless 0 .
$$

On the one hand, there is an injection of foreign demand, which generates domestic wage and profit income and raises domestic expenditure: $\kappa \cdot\left(a_{W B} \cdot \psi^{e}+a_{F} \cdot \pi^{e}\right)$. $d X^{e}>0$. On the other hand, there is a loss of wage income that reduces domestic expenditure: $\kappa \cdot a_{W B} \cdot\left(A^{e}+X^{e}\right) \cdot d \psi^{e}<0$. The net effect is ambiguous.

The foreign demand injection depends crucially on the price elasticity of exports:

$$
d X^{e}=-\varepsilon^{x} \cdot X^{e} \cdot d U C^{e}>0
$$

The higher is the price elasticity of export demand $\varepsilon^{x}>0$, the larger will be the increase in exports. This parameter is crucial, for it regulates the magnitude of the foreign demand injection, which regulates how much additional wage and profit income will be generated in the production of exports, which decides over whether domestic expenditure rises or falls, which ultimately determines whether offshoring raises labor demand or creates unemployment. Only if exports are highly price elastic can the competitiveness effect be large enough to prevent offshoring from creating unemployment.

The Appendix A presents the complete solution, including expressions for $d U C^{e}$ and $d \psi^{e}$. 


\section{Conclusion}

If markups increase in response to offshoring and if the price elasticity of export demand is low, offshoring is more likely to create unemployment than otherwise. Germany was meeting these conditions in the sick man period. First, Germany's wage share, which was trending downward since the 1970s, was falling sharply from the mid-1990s until the crisis. While many factors influence the aggregate wage share, this sharp fall is consistent with the view that the accessibility of low-wage labor in Eastern Europe created threat effects and increased the long-run elasticity of labor demand; in other words, that the new opportunities for efficiency-seeking investments in Central and Eastern Europe led to an increase in the degree of monopoly. The constant-price closure may capture some salient features of the sick man of Europe.

Second, econometric studies frequently find that the price elasticity of demand for Germany's exports is smaller than in most other countries and smaller than one. (See e.g. Christodoulopoulou and Tkačevs 2015 and the references therein.) The explanation typically given is that German firms tend to compete on quality rather than on price, and that the types of goods that German firms are producing and exporting, in particular capital goods, are amenable to product differentiation. The low price elasticity makes it more likely that offshoring was contributing to unemployment and weak demand in Germany.

Higher demand cures demand-deficient unemployment, obviously. If offshoring creates an unemployment problem, a suitable set of expansionary policies could possibly eliminate it or at least reduce it. The same policies, however, would tend to raise import expenditure and worsen the balance of payments. As offshoring proceeds and successive rounds of monetary and fiscal stimulus maintain full employment, there would eventually arise a conflict between the domestic policy objective of reducing unemployment and the sustainability of the country's balance of payments. The particular means by which the labor productivity gain is achieved - higher imports draws attention to the external balance. Offshoring might sharpen a conflict between the objective of maintaining full employment and the objective of improving the external balance.

The present model focuses on one aspect of economic integration, namely the impact on domestic employment and aggregate demand of efficiency-seeking foreign direct investment in low-wage countries. Another aspect of economic integration is that it opens new markets and creates opportunities for market-seeking investment abroad. The present model does not capture the increase in the size of the potential market (although it does recognize that offshoring leads to a competitiveness gain that can raise exports). To study the implications of an enlarged international market in conjunction with offshoring, a two- or $n$-country model would be required.

Acknowledgements In developing the ideas presented here, I have received helpful input from Duncan Foley, Gonçalo Fonseca, Mark Setterfield, Servaas Storm, and Lance Taylor. I have no relevant or material financial interests that relate to the research described in this article.

Funding Information The author declares that he received no funding for this research. 


\section{Compliance with Ethical Standards}

Conflict of interests The author declares that he has no conflict of interest.

Open Access This article is distributed under the terms of the Creative Commons Attribution 4.0 International License (http://creativecommons.org/licenses/by/4.0/), which permits unrestricted use, distribution, and reproduction in any medium, provided you give appropriate credit to the original author(s) and the source, provide a link to the Creative Commons license, and indicate if changes were made.

\section{Appendix A}

The comparative static method allows to analyze the behavior of endogenous variables in response to changes in exogenous variables or parameters in the neighborhood of an equilibrium point without giving particular functional forms to the expenditure function (2) and the export function (3). The system (1)-(11) can be written as follows:

$$
\begin{aligned}
& F^{1}=a\left(\psi \cdot(A+X), \pi \cdot(A+X), \alpha^{a}\right)-A=0, \quad a_{W B}, a_{F}>0, a_{\alpha^{a}}=1 \\
& F^{2}=x\left(R, \alpha^{x}\right)-X=0, \quad x_{R}>0, a_{\alpha^{x}}=1 \\
& F^{3}=m \cdot(A+X)-M=0 \\
& F^{4}=n \cdot(A+X)-N=0 \\
& F^{5}=U C /(1-\pi)-P=0 \\
& F^{6}=W \cdot n+P^{M} \cdot m-U C=0 \\
& F^{7}=P / P^{M}-R=0 \\
& F^{8}=1-\pi-R \cdot m-\psi=0 .
\end{aligned}
$$

Note that $Y, W B$, and $F$ have been eliminated in order to simplify the algebra. The equilibrium condition (1) has been used to express the wage bill as $W B=\psi \cdot(A+X)$ and profits as $F=\pi \cdot(A+X)$, and both magnitudes appear as arguments in the expenditure function $a(\cdot)$. It can be observed that Eqs. 20-27 represents a system of structural equations in implicit form:

$$
\begin{aligned}
F^{1}\left(y^{1}, y^{2}, \ldots, y^{8} ; x^{1}, x^{2}, \ldots, x^{7}\right) & =0 \\
F^{2}\left(y^{1}, y^{2}, \ldots, y^{8} ; x^{1}, x^{2}, \ldots, x^{7}\right) & =0 \\
& \vdots \\
F^{8}\left(y^{1}, y^{2}, \ldots, y^{8} ; x^{1}, x^{2}, \ldots, x^{7}\right) & =0
\end{aligned}
$$


where $y^{i}, i=1, \ldots, 8$, represent the endogenous variables and $x^{i}, i=1, \ldots, 7$, represent the exogenous variables. Throughout the analysis $A, X, M, N, U C, R$, and $\psi$ are treated as endogenous and $n, m, W, P^{M}, \alpha^{a}$, and $\alpha^{x}$ are treated as exogenous. If either $P$ or $\pi$ is treated as the eighth endogenous variable, then the counting rule suggests that the system can be solved in principle. The equilibrium point $E=\left(y^{1 e}, \ldots, y^{8 e}\right)$ is assumed to exist. The functions $F^{1}, \ldots, F^{8}$ are one-time continuously differentiable. If the Jacobian determinant is non-zero,

$$
\operatorname{Det}(J)=\left|\begin{array}{cccc}
\frac{\partial F^{1}}{\partial y^{1}} & \frac{\partial F^{1}}{\partial y^{2}} & \cdots & \frac{\partial F^{1}}{\partial y^{8}} \\
\frac{\partial F^{2}}{\partial y^{1}} & \frac{\partial F^{2}}{\partial y^{2}} & & \vdots \\
\vdots & & \ddots & \\
\frac{\partial F^{8}}{\partial y^{1}} & \cdots & & \frac{\partial F^{8}}{\partial y^{8}}
\end{array}\right| \neq 0,
$$

the implicit function theorem says that Eqs. 20-27 defines the values of the endogenous variables $y^{1}, \ldots, y^{8}$ as one-time continuously differentiable functions of the exogenous variables $x^{1}, \ldots, x^{7}$ in a neighborhood of the equilibrium point $E$. The principal goal of the analysis is to find the total differentials of the reduced forms, assuming that both $n$ and $m$ change. The partial derivatives can be found by means of the comparative static method. The total differential can be constructed from the partial derivatives and the exogenous changes $\Delta n$ and $\Delta m$.

A few words on notation. The superscript $e$ denotes equilibrium values, e.g. $N^{e}$ is the equilibrium value of $N$. Partial derivatives of reduced forms with respect to a parameter or exogenous variable, evaluated at the equilibrium point, are written with the character $\partial$, e.g. $\partial N^{e} / \partial n$. The total differential of equilibrium employment is $d N^{e}=\frac{\partial N^{e}}{\partial n} \cdot \Delta n+\frac{\partial N^{e}}{\partial m} \cdot \Delta m$. The partial derivatives of the expenditure function and the export function are structural parameters, and structural parameters are written with subscripts, e.g. $a_{F}$. An overbar emphasizes that a variable is exogenous, e.g. $\bar{\pi}$.

\section{A.1 Constant-price closure}

This section derives the Eqs. 14 and 15. The variables $A, X, M, N, U C, R, \psi$, and $\pi$ are treated as endogenous, and $\bar{P}$ is an exogenous variable.

Equation 25 immediately gives

$$
d U C^{e}=\frac{\partial U C^{e}}{\partial n} \cdot \Delta n+\frac{\partial U C^{e}}{\partial m} \cdot \Delta m=\bar{W} \cdot \Delta n+\bar{P}^{M} \cdot \Delta m<0 .
$$

The viability condition (13) ensures that the total differential is negative, so unit costs fall in response to offshoring.

Equation 24 gives

$$
d \pi^{e}=-d U C^{e} / \bar{P}>0 .
$$

Equation 27 gives

$$
d \psi^{e}=-d \pi^{e}-R^{e} \cdot \Delta m=\frac{\bar{W}}{\bar{P}} \cdot \Delta n<0 .
$$


The wage share falls because the markup/profit share rises and because imports substitute for domestic labor. Next, consider

$$
\begin{aligned}
& d A^{e}=a_{W B} \cdot\left[d \psi^{e} \cdot\left(A^{e}+X^{e}\right)+\psi^{e} \cdot d A^{e}\right]+a_{F} \cdot\left[d \pi^{e} \cdot\left(A^{e}+X^{e}\right)+\pi^{e} \cdot d A^{e}\right] \\
& d A^{e}=\left(1-a_{W B} \cdot \psi^{e}-a_{F} \cdot \pi^{e}\right)^{-1} \cdot\left(A^{e}+X^{e}\right) \cdot\left(a_{W B} \cdot d \psi^{e}+a_{F} \cdot d \pi^{e}\right) \\
& d A^{e}=\kappa \cdot\left(A^{e}+X^{e}\right) \cdot\left[\left(a_{W B}-a_{F}\right) \cdot \frac{\bar{W}}{\bar{P}} \cdot \Delta n-a_{F} \cdot R^{e} \cdot \Delta m\right]<0 .
\end{aligned}
$$

The first line is the result of totally differentiating (20). To move from the first to the second line, collect the terms that include $d A$ on the left-hand side and then divide by $1-a_{W B} \cdot \psi^{e}-a_{F} \cdot \pi^{e}$, which is the denominator of the multiplier $\kappa$. To move to the third line, plug in $\kappa$ and use the results (28) to (30). The equation's sign is unambiguous. Domestic expenditure falls in response to offshoring because the endogenous adjustment of the markup/profit share redistributes income from wages to profits and because imports substitute for domestic labor.

Equation 23 gives

$$
d N^{e}=-\left(A^{e}+X^{e}\right) \cdot \Delta n+\bar{n} \cdot d A^{e}<0 .
$$

Under the constant-price closure, employment unambiguously falls in response to offshoring because both the productivity effect and the expenditure effect are negative.

\section{A.2 Constant-markup closure}

This section derives the Eqs. 17 through 19. The variables $A, X, M, N, U C, R, \psi$, and $P$ are treated as endogenous variables, and $\bar{\pi}$ is an exogenous variable.

The total differential of unit costs, given by Eq. 28, remains the same. Now the price falls in response to offshoring while the markup remains constant:

$$
d P^{e}=d U C^{e} /(1-\bar{\pi})<0 .
$$

Expressing the price change as a proportion of the equilibrium value will simplify algebraic manipulations and aid interpretation:

$$
\frac{d P^{e}}{P^{e}}=\frac{d U C^{e}}{P^{e} \cdot(1-\bar{\pi})}=\frac{d U C^{e}}{U C^{e}}<0 .
$$

Equation 26 gives

$$
\frac{d R^{e}}{R^{e}}=-\frac{d P^{e}}{P^{e}}=-\frac{d U C^{e}}{U C^{e}}>0 .
$$

A falling domestic-currency price at a given nominal exchange rate implies that international competitiveness improves.

Differentiating (21) gives the change in exports:

$$
d X^{e}=x_{R} \cdot d R^{e}>0 \quad \text { or } \quad \frac{d X^{e}}{X^{e}}=-\varepsilon^{x} \cdot \frac{d U C^{e}}{U C^{e}}>0 .
$$

The text is referring to the price elasticity of export demand whereas the model contains $x_{R}$, which is the slope of export demand. The second equality in Eq. 36 uses $\varepsilon^{x} \equiv x_{R} \cdot R^{e} / X^{e}\left(\varepsilon^{x}>0\right.$ since $\left.x_{R}>0\right)$. 
Equation 27 gives

$$
d \psi^{e}=-d R^{e} \cdot \bar{m}-R^{e} \cdot \Delta m=R^{e} \cdot \bar{m} \cdot\left(\frac{d U C^{e}}{U C^{e}}-\frac{\Delta m}{\bar{m}}\right)<0 .
$$

The wage share falls because the relative price of imports increases, a terms-of-trade effect, and because imports substitute for domestic labor.

Next, consider

$$
\begin{aligned}
d A^{e}= & a_{W B} \cdot\left[d \psi^{e} \cdot\left(A^{e}+X^{e}\right)+\psi^{e} \cdot\left(d A^{e}+d X^{e}\right)\right]+a_{F} \cdot \bar{\pi} \cdot\left(d A^{e}+d X^{e}\right) \\
d A^{e}= & \left(1-a_{W B} \cdot \psi^{e}-a_{F} \cdot \bar{\pi}\right)^{-1} \cdot\left[a_{W B} \cdot\left(A^{e}+X^{e}\right) \cdot d \psi^{e}\right. \\
& \left.+\left(a_{W B} \cdot \psi^{e}+a_{F} \cdot \bar{\pi}\right) \cdot d X^{e}\right] \\
d A^{e}= & \kappa \cdot\left[a_{W B} \cdot R^{e} \cdot M^{e} \cdot\left(\frac{d U C^{e}}{U C^{e}}-\frac{\Delta m}{m}\right)\right. \\
& \left.-\left(a_{W B} \cdot \psi^{e}+a_{F} \cdot \bar{\pi}\right) \cdot \varepsilon^{x} \cdot X^{e} \cdot \frac{d U C^{e}}{U C^{e}}\right] \gtreqless 0 .
\end{aligned}
$$

The first line is the result of totally differentiating (20). To move from the first to the second line, collect the terms that include $d A^{e}$ on the left-hand side and then divide by the denominator of the multiplier $\kappa$. To move to the third line, use Eq. 36 and Eq. 37 and substitute $M^{e}=\bar{m} \cdot\left(A^{e}+X^{e}\right)$. The total differential (38) cannot be signed. The condition for it to be positive is

$$
a_{W B} \cdot R^{e} \cdot M^{e} \cdot\left(\frac{d U C^{e}}{U C^{e}}-\frac{\Delta m}{\bar{m}}\right)>\left(a_{W B} \cdot \psi^{e}+a_{F} \cdot \bar{\pi}\right) \cdot \varepsilon^{x} \cdot X^{e} \cdot \frac{d U C^{e}}{U C^{e}} .
$$

By assuming that trade is balanced at the initial equilibrium point, $X^{e}=R^{e} \cdot M^{e}$, the condition simplifies to

$$
a_{W B} \cdot\left(\frac{d U C^{e}}{U C^{e}}-\frac{\Delta m}{\bar{m}}\right)>\left(a_{W B} \cdot \psi^{e}+a_{F} \cdot \bar{\pi}\right) \cdot \varepsilon^{x} \cdot \frac{d U C^{e}}{U C^{e}},
$$

which can be written as

$$
\varepsilon^{x}>\frac{a_{W B}}{a_{W B} \cdot \psi^{e}+a_{F} \cdot \bar{\pi}} \cdot\left(1-\frac{\frac{\Delta m}{\bar{m}}}{\frac{d U C^{e}}{U C^{e}}}\right) .
$$

From $a_{F}<a_{W B}$ and $0<\psi^{e}+\bar{\pi}<1$, it follows that $a_{W B} \cdot \psi^{e}+a_{F} \cdot \bar{\pi}<a_{W B}$ or $a_{W B} /$ $\left(a_{W B} \cdot \psi^{e}+a_{F} \cdot \bar{\pi}\right)>1$. The term in the bracket is positive and larger than one as well. Thus, a necessary condition for domestic expenditure to rise in response to offshoring is that the price elasticity of exports is larger than one.

Recall that the viability condition ensures that $\frac{d U C^{e}}{U C^{e}}$ is negative. As the viability condition tends to zero, that is, as offshoring becomes less profitable, the size of $-\frac{\Delta m}{\bar{m}} / \frac{d U C^{e}}{U C^{e}}$ increases and the condition (41) will be violated. In other words, if a fall in domestic expenditure is to be avoided, the smaller is the cost advantage from offshoring, the larger will have to be the price elasticity of exports.

Equation 23 gives

$$
d N^{e}=\Delta n \cdot\left(A^{e}+X^{e}\right)+\bar{n} \cdot\left(d A^{e}+d X^{e}\right) \gtreqless 0 .
$$


Under the constant-markup closure, the change in employment cannot be signed. The productivity effect is negative, but the scale effect may be positive. Using Eq. 38, the condition for employment to rise in response to offshoring is

$$
\begin{aligned}
\Delta n \cdot & \left.\left(A^{e}\right)+X^{e}\right)+\bar{n} \cdot\left(\kappa \cdot \left[a_{W B} \cdot\left(A^{e}+X^{e}\right) \cdot d \psi^{e}\right.\right. \\
& \left.\left.+\left(a_{W B} \cdot \psi^{e}+a_{F} \cdot \bar{\pi}\right) \cdot d X^{e}\right]+d X^{e}\right)>0 .
\end{aligned}
$$

Observing that $1+\kappa \cdot\left(a_{W B} \cdot \psi^{e}+a_{F} \cdot \bar{\pi}\right)=\kappa$, the relation can be written as

$$
\Delta n \cdot\left(A^{e}+X^{e}\right)+\bar{n} \cdot \kappa \cdot\left[a_{W B} \cdot\left(A^{e}+X^{e}\right) \cdot d \psi^{e}+d X^{e}\right]>0 .
$$

Using Eqs. 36 and 37, the condition reads

$$
\Delta n \cdot\left(A^{e}+X^{e}\right)+\bar{n} \cdot \kappa \cdot\left[a_{W B} \cdot\left(A^{e}+X^{e}\right) \cdot X^{e} \cdot R^{e} \cdot \bar{m} \cdot\left(\frac{d U C^{e}}{U C^{e}}-\frac{\Delta m}{\bar{m}}\right)-\varepsilon^{x} \cdot \frac{d U C^{e}}{U C^{e}}\right]>0 .
$$

By assuming that trade is balanced at the equilibrium point and substituting $M^{e}=$ $\bar{m} \cdot\left(A^{e}+X^{e}\right)$, the condition simplifies to

$$
\varepsilon^{x}>\frac{1}{\kappa \cdot \bar{m}} \cdot \frac{\frac{\Delta n}{\bar{n}}}{\frac{d U C^{e}}{U C^{e}}}+a_{W B} \cdot\left(1-\frac{\frac{\Delta m}{\bar{m}}}{\frac{d U C^{e}}{U C^{e}}}\right) .
$$

Ignoring two out three terms on the right-hand side, a necessary condition for employment to rise in response to offshoring is that the price elasticity of exports is larger than $a_{W B}$. But the price elasticity has to be larger than that; it has to counteract the other two terms as well. Once again, $\frac{d U C^{e}}{U C^{e}}$ appears in the denominator. If a fall in domestic employment is to be avoided, the smaller is the cost advantage from offshoring, the larger will have to be the price elasticity of exports.

\section{A.3 Stability}

To analyze the stability of the system, assume that its out-of-equilibrium behavior is defined by the adjustment equations

$$
\begin{aligned}
& \dot{A}=k^{1} \cdot\left[a\left(\psi \cdot(A+X), \pi \cdot(A+X), \alpha^{a}\right)-A\right] \\
& \dot{X}=k^{2} \cdot[x(R)-X],
\end{aligned}
$$

where $k^{1}, k^{2}>0$ are parameters setting the speed of adjustment and the dot over a variable indicates a derivative with respect to time. Only the out-of-equilibrium behavior of the Eqs. 20 and 21 is defined, and the Eqs. 22 through 27 are assumed to be satisfied instantaneously. Regardless of whether $P$ is exogenous and $\pi$ is endogenous, or vice versa, the Jacobian matrix of the linearized system is

$$
J=\left[\begin{array}{cc}
a_{W B} \cdot \psi+a_{F} \cdot \pi-1 & a_{W B} \cdot \psi+a_{F} \cdot \pi \\
0 & -1
\end{array}\right]
$$


It turns out that the Jacobian determinant is positive if the multiplier is positive, which is commonly assumed to be the case and indeed has been assumed throughout the article. Given the positive Jacobian determinant and a negative trace,

$$
\begin{aligned}
\operatorname{Det}(J) & =1-a_{W B} \cdot \psi-a_{F} \cdot \pi>0 \\
\operatorname{Tr}(J) & =a_{W B} \cdot \psi+a_{F} \cdot \pi-2<0,
\end{aligned}
$$

the system is dynamically stable.

In order to avoid overly complicated mathematical expressions, the above equations have carried along $\psi$ and $R$ (endogenous variables) and $\pi$ (exogenous or endogenous depending on the closure). A complete solution would express these variables in terms of parameters and exogenous variables. If $P$ is exogenous, the following substitutions can be made:

$$
\begin{aligned}
& \pi^{e}=1-U C^{e} / \bar{P}=1-\left(\bar{W} \cdot \bar{n}+\bar{P}^{M} \cdot \bar{m}\right) / \bar{P} \\
& \psi^{e}=1-\pi^{e}-R^{e} \cdot \bar{m}=\left(\bar{W} \cdot \bar{n}+\bar{P}^{M} \cdot \bar{m}\right) / \bar{P}-\bar{P}^{M} \cdot \bar{m} / \bar{P}=\bar{W} \cdot \bar{n} / \bar{P} \\
& R^{e}=\bar{P}^{M} / \bar{P} .
\end{aligned}
$$

If $\pi$ is exogenous, these substitutions can be made:

$$
\begin{aligned}
\pi & =\bar{\pi} \\
\psi^{e} & =1-\bar{\pi}-R^{e} \cdot \bar{m}=\bar{W} \cdot \bar{n} / P^{e}=\bar{W} \cdot \bar{n} \cdot(1-\bar{\pi}) /\left(\bar{W} \cdot \bar{n}+\bar{P}^{M} \cdot \bar{m}\right) \\
R^{e} & =\bar{P}^{M} / P^{e}=\bar{P}^{M} \cdot(1-\bar{\pi}) /\left(\bar{W} \cdot \bar{n}+\bar{P}^{M} \cdot \bar{m}\right) .
\end{aligned}
$$

\section{References}

Ahlers E, Öz F, Ziegler A (2007) Standortverlagerung in Deutschland: Einige empirische und politische Befunde. Hans-Böckler-Stiftung, Düsseldorf

AMECO (2017) Annual macroeconomic database. Database, European Commission

Amiti M, Wei SJ (2005) Fear of service outsourcing: is it justified? Econ Policy 20(42):308-347. https://doi.org/10.1111/j.1468-0327.2005.00140.x

Amiti M, Wei SJ (2009) Does service offshoring lead to job losses? Evidence from the United States. In: Reinsdorf M, Slaughter M (eds) International trade in services and intangibles in the era of globalization. University of Chicago Press, pp 227-243

Bachmann R, Braun S (2011) The impact of international outsourcing on labour market dynamics in Germany. Scottish Journal of Political Economy 58(1):1-28. https://doi.org/10.1111/j.1467-9485.2010. 00535.x

Bhaduri A, Marglin S (1990) Unemployment and the real wage: the economic basis for contesting political ideologies. Camb J Econ 14(4):375-93

Bhagwati J, Panagariya A, Srinivasan TN (2004) The muddles over outsourcing. J Econ Perspect 18(4): 93-114

Blecker RA (1989) International competition, income distribution and economic growth. Camb J Econ 13(3):395-412

Blecker RA (2011) Open economy models of distribution and growth. In: Hein E, Stockhammer E (eds) A modern guide to Keynesian macroeconomics and economic policies. Edward Elgar, Cheltenham

Blecker RA (2016) Wage-led versus profit-led demand regimes: the long and the short of it. Review of Keynesian Economics 4(4):373-390. https://doi.org/10.4337/roke.2016.04.02

Burgess DF (1974) Production theory and the derived demand for imports. J Int Econ 4(2):103-117. https://doi.org/10.1016/0022-1996(74)90055-5 
Bussière M, Callegari G, Ghironi F, Sestieri G, Yamano N (2013) Estimating trade elasticities: demand composition and the trade collapse of 2008-2009. Am Econ J Macroecon 5(3):118-151. https://doi.org/ 10.1257/mac.5.3.118

Christodoulopoulou S, Tkačevs O (2015) Measuring the effectiveness of cost and price competitiveness in external rebalancing of Euro area countries: what do alternative HCIs tell us? Empirica:1-45. https://doi.org/10.1007/s10663-015-9303-5

Davidson C, Matusz SJ (2009) International trade with equilibrium unemployment. Princeton University Press, Princeton

Davidson C, Martin L, Matusz S (1999) Trade and search generated unemployment. J Int Econ 48(2):271299. https://doi.org/10.1016/S0022-1996(98)00040-3

Dube A, Reddy SG (2014) Threat effects and trade: wage discipline through product market competition. Journal of Globalization and Development 4(2):213-252. https://doi.org/10.1515/jgd-2012-0019

Dustmann C, Fitzenberger B, Schönberg U, Spitz-Oener A (2014) From sick man of Europe to economic superstar: Germany's resurgent economy. J Econ Perspect 28(1):167-188

Elms DK, Low P (2013) Global value chains in a changing world. Report, Fung Global Institute and World Trade Organization

Foley DK, Michl TR (1999) Growth and distribution. Harvard University Press, Cambridge

Foster N, Stehrer R, Timmer M (2013) International fragmentation of production, trade and growth: impacts and prospects for EU member States European Economy - Economic Paper 484, European Commission, Directorate-General for Economic and Financial Affairs

Gandolfo G (2010) Economic dynamics, 4th edn. Springer, Heidelberg

Geishecker I (2008) The impact of international outsourcing on individual employment security: a microlevel analysis. Labour Econ 15(3):291-314. https://doi.org/10.1016/j.labeco.2007.06.015

Görg H, Görlich D (2015) Offshoring, wages and job security of temporary workers. Rev World Econ 151(3):533-554. https://doi.org/10.1007/s10290-015-0220-2

Grossman GM, Rossi-Hansberg E (2008) Trading tasks: a simple theory of offshoring. Am Econ Rev 98(5):1978-1997

Harrison A, McLaren J, McMillan M (2011) Recent perspectives on trade and inequality. Annual Review of Economics 3(1):261-289. https://doi.org/10.1146/annurev.economics.102308.124451

Harrod R (1933) International economics. Cambridge University Press, Cambridge

Helpman E, Itskhoki O (2010) Labour market rigidities, trade and unemployment. Rev Econ Stud 77(3):1100-1137. https://doi.org/10.1111/j.1467-937X.2010.00600.x

Helpman E, Itskhoki O (2015) Trade liberalization and labor market dynamics with heterogeneous firms. Unpublished Manuscript, Harvard University

Johnson RC, Noguera G (2012a) Accounting for intermediates: production sharing and trade in value added. J Int Econ 86(2):224-236. https://doi.org/10.1016/j.jinteco.2011.10.003

Johnson RC, Noguera G (2012b) Fragmentation and trade in value added over four decades. Working Paper 18186, National Bureau of Economic Research

Johnson RC, Noguera G (2012c) Proximity and production fragmentation. Am Econ Rev 102(3):407-411

Jones RW (2000) Globalization and the theory of input trade, 1st edn. The MIT Press, Cambridge

Kalecki M (1954) Theory of economic dynamics an essay on cyclical and long-run changes in capitalist economy. George Allen and Unwin

Kennedy C, Thirlwall AP (1979) The input-output formulation of the foreign trade multiplier. Aust Econ Pap 18(32): 173

Kiefer D, Rada C (2015) Profit maximising goes global: the race to the bottom. Camb J Econ 39(5):13331350. https://doi.org/10.1093/cje/beu040

Kohli U (1991) Technology, duality and foreign trade: the GNP function approach to modeling imports and exports. University of Michigan Press, Ann Arbor

Krzywdzinski M (2014) How the EU's Eastern enlargement changed the German productive model. The case of the automotive industry. Revue de la régulation Capitalisme, institutions, pouvoirs (15)

Lavoie M (2014) Post-Keynesian economics: new foundations. Edward Elgar Pub

Lavoie M, Stockhammer E (2013) Wage-led growth: concept, theories and policies. In: Wage-led growth, advances in labour studies. Palgrave Macmillan, London, pp 13-39

Machlup F (1943) International trade and the national income multiplier. Augustus M. Kelley, New York

Melitz MJ (2003) The impact of trade on intra-industry reallocations and aggregate industry productivity. Econometrica 71(6):1695-1725. https://doi.org/10.1111/1468-0262.00467

Milberg W, Winkler D (2013) Outsourcing economics: global value chains in capitalist development. Cambridge University Press, Cambridge 
Naastepad C, Storm S (2007) OECD demand regimes (1960-2000). Journal of Post Keynesian Economics 29(2):211-246. https://doi.org/10.2753/PKE0160-3477290203

OECD (2007) Offshoring and employment: trends and impacts. Organisation for economic co-operation and development

Onaran O, Obst T (2016) Wage-led growth in the Eu15 member-States: the effects of income distribution on growth, investment, trade balance and inflation. Camb J Econ 40(6):1517-1551. https://doi.org/ 10.1093/cje/bew009

Rezai A (2015) Demand and distribution in integrated economies. Camb J Econ 39(5):1399-1414. https://doi.org/10.1093/cje/beu060

Rodrik D (1997) Has globalization gone too far? Peterson Institute for International Economics

Stehrer R (2013) Accounting relations in bilateral value added trade. wiiw Working Paper 101, The Vienna Institute for International Economic Studies, wiiw

Taylor L (2004) Reconstructing macroeconomics: structuralist proposals and critiques of the mainstream. Harvard University Press, Cambridge

Timmer MP, Los B, Stehrer R, de Vries GJ (2013) Fragmentation, incomes and jobs: an analysis of European competitiveness. Econ Policy 28(76):613-661. https://doi.org/10.1111/1468-0327.12018

von Arnim R, Tavani D, Carvalho L (2014) Redistribution in a Neo-Kaleckian two-country model. Metroeconomica 65(3):430-459. https://doi.org/10.1111/meca.12047

Winkler D (2010) Services offshoring and its impact on productivity and employment: evidence from Germany, 1995-2006. World Econ 33(12):1672-1701. https://doi.org/10.1111/j.1467-9701.2010.01269.x

Wright GC (2014) Revisiting the employment impact of offshoring. Eur Econ Rev 66:63-83. https://doi.org/10.1016/j.euroecorev.2013.11.008 